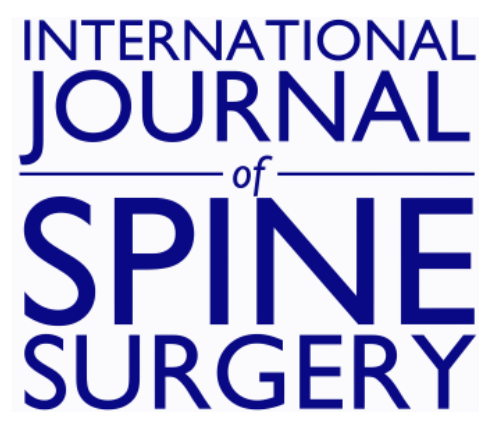

\title{
Morphometric Study of the Cervical Spinal Canal Content and the Vertebral Artery
}

\author{
EVREN AYDOGMUS and SAFIYE ÇAVDAR
}

Int J Spine Surg 2020, 14 (4) 455-461

doi: https://doi.org/10.14444/7060

http://ijssurgery.com/content/14/4/455

This information is current as of April 26, 2023.

Email Alerts Receive free email-alerts when new articles cite this article. Sign up at: http://ijssurgery.com/alerts 


\title{
Morphometric Study of the Cervical Spinal Canal Content and the Vertebral Artery
}

\author{
EVREN AYDOĞMUŞ ${ }^{1}$, SAFIYE ÇAVDAR ${ }^{2}$ \\ ${ }^{I}$ Department of Neurosurgery, Dr. Lütfi Kirdar Kartal Education and Research Hospital, Istanbul, Turkey; ${ }^{2}$ Department of Anatomy, Koc University, \\ School of Medicine Istanbul, Turkey
}

\begin{abstract}
Background: The morphological features of the cervical spinal nerves (C1-C8), their dimensions, and their anatomical relations with the vertebral artery are important for safe spinal surgery. The aim of the present study is to give detailed morphological data of the region to avoid complications.

Methods: Five formalin-fixed adult cadavers were studied. The cervical spinal nerves and the vertebral artery were exposed via the posterior approach, and detailed anatomy and morphometric measurements were evaluated. The following measurements were documented: angles between the spinal nerve and the spinal cord of $\mathrm{C} 1$ to $\mathrm{C} 8$, width of the $\mathrm{C} 1$ to $\mathrm{C} 8$ spinal nerves at their origin, distance of the spinal cord to the vertebral artery, number of dorsal rootlets, length of the dorsal root entry zone of $\mathrm{C} 1$ to $\mathrm{C} 8$, and distance between respective spinal nerves. Further, the average length and width of the transverse foramen were measured.

Results: The average angle between the spinal cord and the spinal nerve within the vertebral canal ranged between 54 and 87 degrees and were most acute at C5 (54 degrees) compared to the rest of the cervical spinal nerves. The average width of the spinal nerves (mean $\pm \mathrm{SD})$, was thickest at C5 $(5.7 \pm 1.2 \mathrm{~mm})$ and C6 (5.8 $\pm 0.7 \mathrm{~mm})$. The average largest distance between the vertebral artery and the spinal cord was at C2 $(14.3 \pm 1.7 \mathrm{~mm})$ and the smallest at C5 (7.3 \pm 0.9 $\mathrm{mm})$ and C6 $(7.3 \pm 2.2 \mathrm{~mm})$ spinal levels. The number of dorsal rootlets was most numerous at C6 (8.25 \pm 0.6$)$ and C7 (7.25 \pm 0.9$)$. The dorsal root entry zone length was the largest at C5 $(13.0 \pm 1.6 \mathrm{~mm})$ and C6 (13.75 $\pm 0.5 \mathrm{~mm})$. The distance between respective spinal nerves was largest between $\mathrm{C} 2$ and $\mathrm{C} 3(11.8 \pm 2.2)$ and $\mathrm{C} 7$ and $\mathrm{C} 8$ (11.5 \pm 0.6$)$.

Conclusion: The knowledge of detailed anatomy of the cervical spine (C1-C8) and its relations with the vertebral artery will reduce the unwanted damage to the vital structures of the region.
\end{abstract}

Cervical Spine

Keywords: dorsal cervical nerve roots, spinal cord, vertebral artery

\section{INTRODUCTION}

The anatomy of the cervical spine, with its high physical mobility and its proximity to vital structures such as the vertebral artery and the cervical spinal nerves, makes this region clinically important. Surgery on the cervical spine is performed for tumors and metastases, ${ }^{1,2}$ vertebral artery loop, ${ }^{3,4}$ degenerative disease, and trauma. ${ }^{5}$ During surgery in this region there is a potential risk of injuring the spinal cord, the vertebral artery, and the nerve roots.

In recent years endoscopy has been widely used for various treatments in medicine, although its use in cervical spinal surgery is rare because of technical limitations. However, due to an unprecedented pace in technology, a device that permits a safe steer inside the spinal canal will likely be developed in the very near future. Its use requires a detailed knowledge of the spinal morphology and accurate measurements of its different components.

There are numerous studies using radiological instruments (myelography, ultrasonography, computed tomography, and magnetic resonance imaging) to measure various dimensions of the contents of the cervical canal. ${ }^{6-9}$ However, there are few morphometric cadaver studies on the detailed anatomy of the cervical spinal canal content. ${ }^{8}$ Thus the aim of the present study is to give detailed anatomical knowledge of the cervical spinal nerves, the dorsal rootlets, and the relationship of the vertebral artery to the spinal cord in order to make a suitable surgical treatment for cervical spine disorders. Further, as endoscopic treatment is becoming popular in modern medicine, the data obtained from the present study may help to develop new devices. 

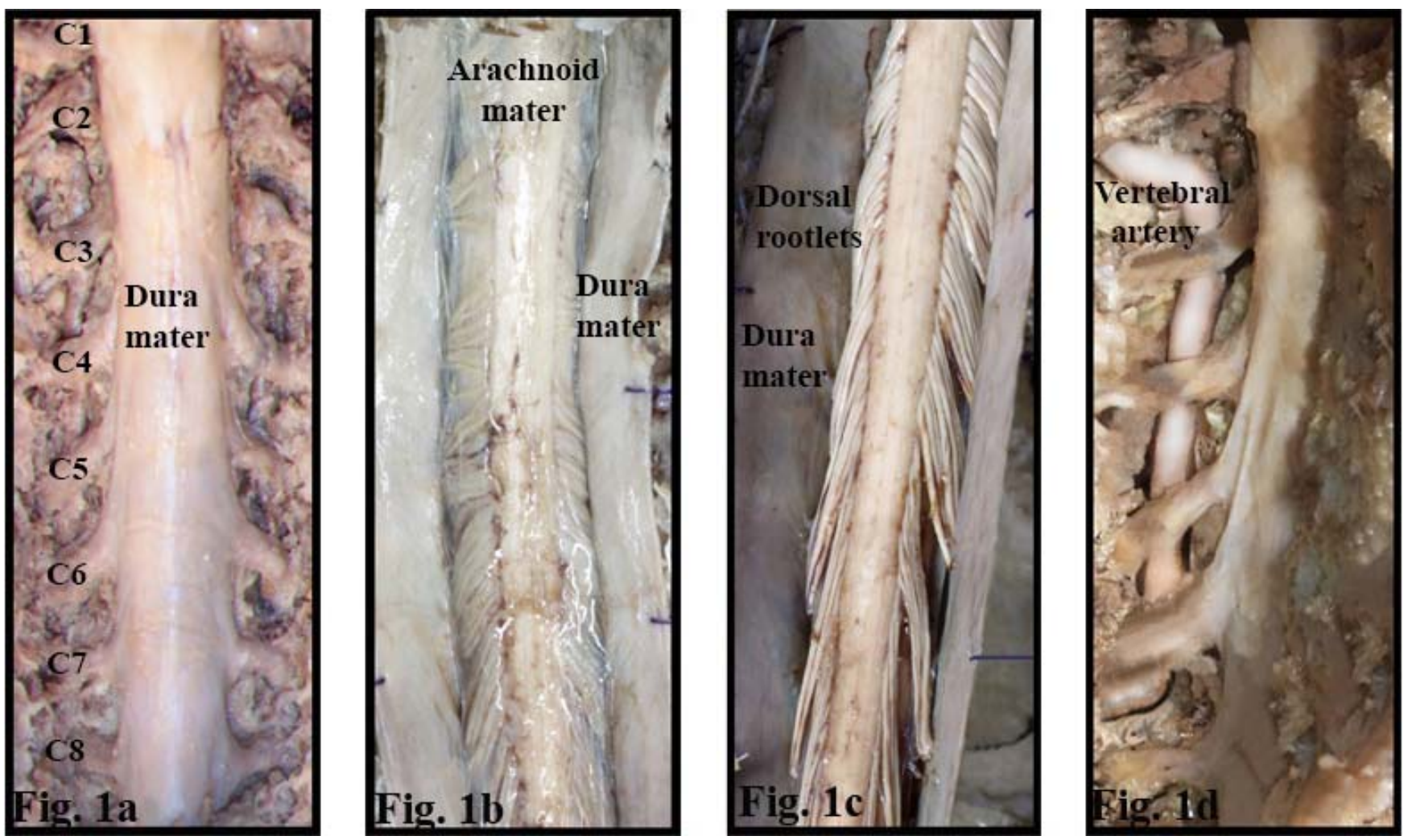

Figure 1. The skin, subcutaneous tissue, muscles of the region, and the spinous processes and laminae of $\mathrm{C} 1$ to $\mathrm{C} 7$ vertebrae were removed. (a) The dura mater and the cervical spinal nerves within the dura were exposed. (b) The dura mater was longitudinally incised and the arachnoid matter was exposed. (c) The arachnoid matter was reflected and the dorsal rootlets were exposed. (d) Anterior to the spinal nerves the V2 segment of the vertebral artery was exposed.

\section{METHODS}

\section{Anatomical Dissection}

Five formalin-fixed adult human cadavers (1 female and 4 males) were used. The age range of the cadavers was 59 to 75 years (mean, 67 years). None had grossly visible deformities of the vertebral column, spinal cord, or spinal canal. Each cadaver was placed in prone position, and the skin, subcutaneous tissue, and superficial and deep musculature were removed along the length of the cervical spine. The spinous processes and laminae of the $\mathrm{C} 1$ to $\mathrm{C} 7$ vertebrae were removed using a highspeed drill and rongeurs. The ligamentum flavum was excised. The dura mater, arachnoid, and the cervical spinal nerves were exposed (Figures 1a,b,c). Deep to the spinal nerves the V2 segment of the vertebral artery was exposed (Figure 1d). The following morphometric measurements for all cervical spinal nerves were made on 5 cadavers and on both sides: (1) the angle between the cervical spinal nerves and the longitudinal axis of the spinal cord (Figure 2a), (2) the width of the cervical (C1-C8) spinal nerves at their origin (Figure 2a), (3) the distance between respective cervical spinal nerves (measurements were made as soon as they exit from the spinal cord) (Figure 2a), and (4) the relationships of the cervical spinal nerves with the vertebral artery (the distance between the medial border of the vertebral artery to the exit point of the cervical spinal nerves from the spinal cord) (Figure 2a).
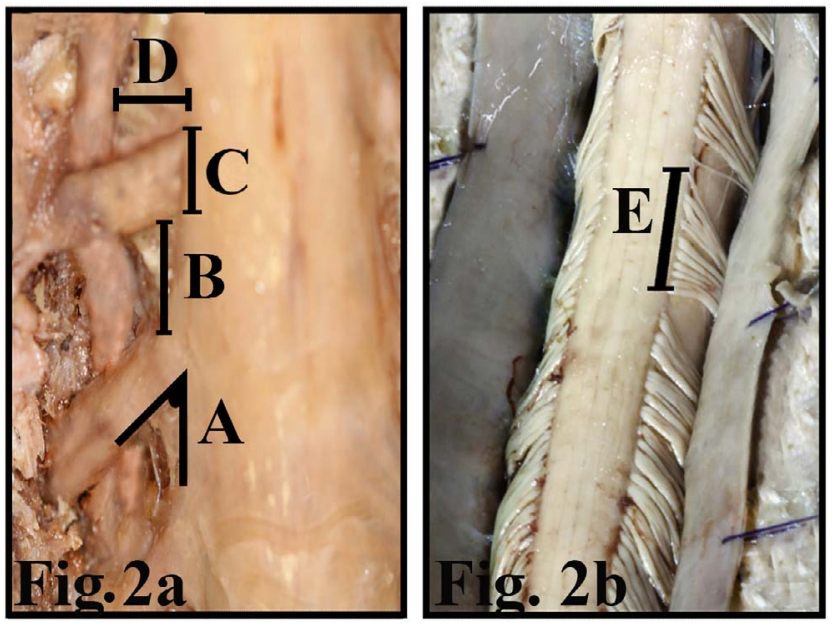

Figure 2. $(a, b)$ Measurements made on the cervical spinal nerve and the vertebral artery. $A$ indicates angles between the spinal nerve and the spinal cord; B, distance between respective spinal nerves; $\mathrm{C}$, width of spinal nerves; $\mathrm{D}$, distance between of the spinal cord and the vertebral artery; E, the length of dorsal root entry zone. 


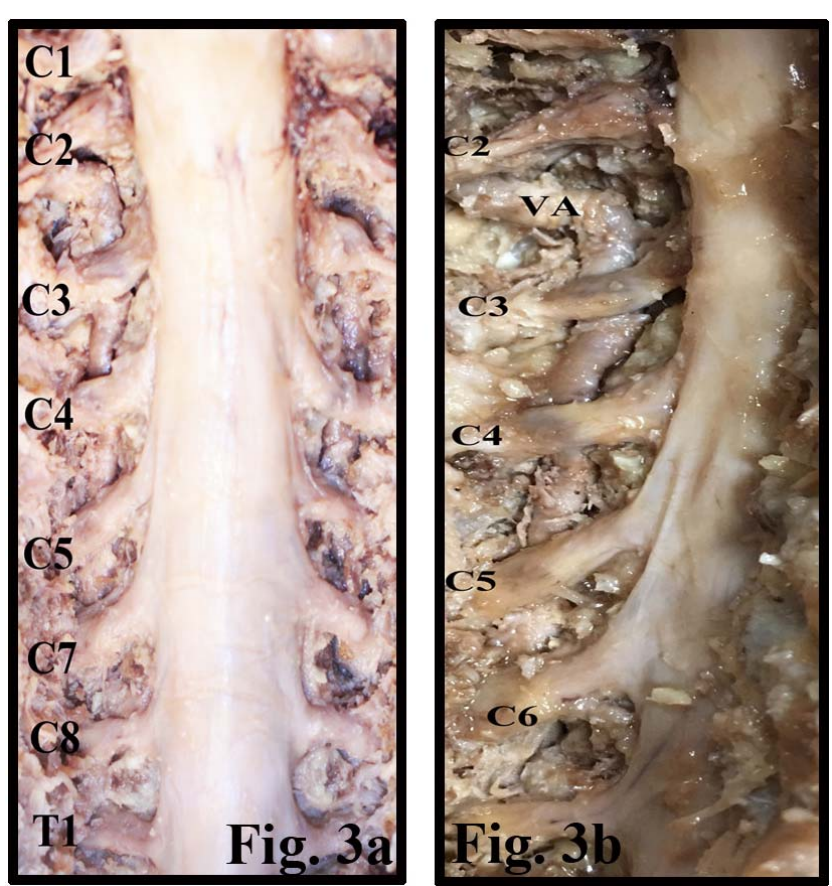

Figure 3. (a) The spinal cord and the cervical spinal nerves have been exposed within the vertebral canal. (b) The relation of the spinal nerve and the vertebral artery (VA) has been exposed.

Subsequent to the above measurements a midline longitudinal incision was made and the dorsal cervical spinal roots were exposed. Then the number of dorsal rootlets and the dorsal root entry zone (DREZ) length of cervical spinal nerves were measured (Figure 2b). A single researcher recorded all measurements on a cadaver in the constant prone position. Linear measurements were made with a compass and angles were measured by a protractor.

\section{RESULTS}

\section{The Angle of the Cervical Spinal Nerves}

The upper cervical spinal nerves run more or less horizontally to reach their respective intervertebral foramen within the vertebral canal; however, the lower cervical spinal nerves run obliquely, forming a narrower angle with the long axis of the spinal cord (Figures 1a, 3a,b). The average angle (mean $\pm \mathrm{SD}$ ), ranged from $54.5^{\circ} \pm 3.3^{\circ}$ to $87.8^{\circ} \pm 2.2^{\circ}$ with an average of $63.9^{\circ}$ at cervical spinal levels. The most obtuse angles were measured at $\mathrm{C} 1\left(87.8^{\circ} \pm 2.2^{\circ}\right)$ and $\mathrm{C} 8\left(83^{\circ} \pm 3.7^{\circ}\right)$ and the most acute angle was measured at the $\mathrm{C} 5\left(54.5^{\circ} \pm 3.3^{\circ}\right)$ cervical spinal level (Table 1). No significant difference was measured between the angles of the cervical spinal nerves of the left and right sides.

\section{The Width of Cervical Spinal Nerves}

The average width of cervical spinal nerves was 5 $\mathrm{mm}$ (Figures 3a,b). The average width of the C1 (2.1 $\pm 0.1 \mathrm{~mm})$ was thinnest; C5 $(5.7 \pm 1.2 \mathrm{~mm})$ and C6 $(5.8 \pm 0.7 \mathrm{~mm})$ were the thickest spinal nerves (Table 1).

\section{The Relations of the Vertebral Artery to the Spinal Cord}

The vertebral artery lies anterior to the cervical spinal nerves while ascending through the transverse foramen of cervical vertebrae (Figures 1d, 3b). The distance between the vertebral artery and the spinal cord was the largest at $\mathrm{C} 2(14.3 \pm 1.7 \mathrm{~mm})$ and was smallest at the C5 $(7.3 \pm 0.9 \mathrm{~mm})$ and C6 $(7.3 \pm 2.2$ $\mathrm{mm}$ ) spinal levels (Table 1).

\section{The Number of Rootlets and DREZ Distance}

The average number of dorsal rootlets increased progressively from $\mathrm{C} 1$ to $\mathrm{C} 6$ and was most numerous at $\mathrm{C} 6(8.3 \pm 0.6)$ and $\mathrm{C} 7(7.3 \pm 0.9)$. Parallel to the increase in number of rootlets, increases in DREZ length were observed (Table 1). The largest average DREZ length was observed at C5 $(13.0 \pm 1.6 \mathrm{~mm})$ and C6 $(13.8 \pm 0.5 \mathrm{~mm})$ (Table 1). No significant difference was measured between

Table 1. Shows the average angles (mean $\pm \mathrm{SD}$ ), widths of $\mathrm{C} 1$ to $\mathrm{C} 8$ spinal nerves, distance between vertebral artery and spinal cord, number of dorsal rootlets, and length of dorsal root entry zone.

\begin{tabular}{|c|c|c|c|c|c|}
\hline & Angle $\left({ }^{\circ}\right)$ & $\begin{array}{l}\text { Width of Spinal } \\
\text { Nerve }(\mathrm{mm})\end{array}$ & $\begin{array}{l}\text { Distance Between } \\
\text { Vertebral Artery and } \\
\text { Spinal Cord (mm) }\end{array}$ & $\begin{array}{c}\text { No. of } \\
\text { Dorsal Rootlets }\end{array}$ & $\begin{array}{c}\text { DREZ } \\
\text { Length }(\mathrm{mm})\end{array}$ \\
\hline $\mathrm{Cl}$ & $87.8 \pm 2.2$ & $2.1 \pm 0.1$ & $2.6 \pm 0.5$ & $1 \pm 0.0$ & $1 \pm 0.0$ \\
\hline $\mathrm{C} 2$ & $55.0 \pm 3.8$ & $4.0 \pm 0.7$ & $14.3 \pm 1.7$ & $4.3 \pm 1.5$ & $5.8 \pm 0.5$ \\
\hline $\mathrm{C} 3$ & $55.0 \pm 4.0$ & $5.1 \pm 1.1$ & $8.0 \pm 0.8$ & $5.6 \pm 1.2$ & $9.8 \pm 0.9$ \\
\hline $\mathrm{C} 4$ & $56.0 \pm 4.1$ & $5.5 \pm 0.9$ & $7.8 \pm 0.9$ & $6.3 \pm 1.5$ & $11.8 \pm 0.9$ \\
\hline $\mathrm{C} 5$ & $54.5 \pm 3.3$ & $5.7 \pm 1.2$ & $7.3 \pm 0.9$ & $6.3 \pm 1.2$ & $13.0 \pm 1.6$ \\
\hline C6 & $56.7 \pm 4.0$ & $5.8 \pm 0.7$ & $7.3 \pm 2.2$ & $8.3 \pm 0.6$ & $13.8 \pm 0.5$ \\
\hline C7 & $64.0 \pm 3.9$ & $5.4 \pm 0.9$ & & $7.3 \pm 0.9$ & $12.8 \pm 1.5$ \\
\hline $\mathrm{C} 8$ & $83.0 \pm 3.7$ & $5.1 \pm 1.1$ & & $6.8 \pm 0.9$ & $12.0 \pm 0.8$ \\
\hline
\end{tabular}

Abbreviation: DREZ, dorsal root entry zone. 
Table 2. Shows the average distance (mean $\pm S D$ ), between respective spinal nerves.

\begin{tabular}{lc}
\hline Cervical Spinal Levels & $\begin{array}{c}\text { Distance Between } \\
\text { Spinal Nerves }(\mathbf{m m})\end{array}$ \\
\hline C1-C2 & $10.3 \pm 2.8$ \\
C2-C3 & $11.8 \pm 2.2$ \\
C3-C4 & $10.0 \pm 0.8$ \\
C4-C5 & $9.3 \pm 0.9$ \\
C5-C6 & $9.0 \pm 0.8$ \\
C6-C7 & $10.5 \pm 0.6$ \\
C7-C8 & $11.5 \pm 0.6$ \\
\hline
\end{tabular}

the number of rootlets and the length of DREZ of the left and right sides.

\section{The Distance Between Respective Cervical Spinal Nerves}

The distance between respective cervical spinal nerves ranged from $9 \pm 0.8$ to $11.8 \pm 2.2 \mathrm{~mm}$ with an average of $10.3 \pm 1.0 \mathrm{~mm}$ (Table 2, Figure 3a). The distances between the $\mathrm{C} 2$ and $\mathrm{C} 3(11.8 \pm 2.2$ $\mathrm{mm})$ and $\mathrm{C} 7$ and $\mathrm{C} 8(11.5 \pm 0.6)$ were the largest (Table 2). Measurements did not show statistically significant difference between right and left sides.

\section{DISCUSSION}

Although avoiding unfortunate injury is not always possible, understanding the locations and relations of the anatomic structures is the only safeguard against unwarranted damage.

\section{The Angle Between the Cervical Spinal Rootlets and the Longitudinal Axis of the Spinal Cord}

Due to the disproportionate growth of the spinal cord and the vertebral column, the spinal nerves run obliquely from their segments of origin to the corresponding intervertebral foramen. The oblique course of the spinal nerve rootlets can cause retraction at mobile segments of the vertebral column. ${ }^{10}$

The cervical segment of the vertebral column is mobile, thus the angle of the cervical spinal rootlets can change during flexion, extension, and lateral flexion of the neck. Therefore, all measurements on the cadaver were made in a standard position. Hung and Zhao ${ }^{11}$ measured the angles between the cervical rootlets from $\mathrm{C} 5$ to $\mathrm{T} 1$ and reported that the angle sustained by the rootlets to the cord ranged from $45^{\circ}$ to $89^{\circ}$ at $\mathrm{C} 5$ and $23^{\circ}$ to $41^{\circ}$ at $\mathrm{T} 1$. The present study showed that the average angle from $\mathrm{C} 1$ to $\mathrm{C} 8$ ranged between $54.5^{\circ}$ and $87.8^{\circ}$; the most acute angle was measured at $\mathrm{C} 5\left(54.5^{\circ} \pm 3.3^{\circ}\right)$ and the most obtuse angle at $\mathrm{C} 1\left(87.8^{\circ} \pm 2.2^{\circ}\right)$ level.
Frykholm $^{12}$ reported no consistent difference in the morphology between rootlets. However, the results of the present study and the study by Shinomiya et $\mathrm{al}^{13}$ showed that the roots of C5 were more acute than the lower cervical spinal nerves. Sunderland ${ }^{14}$ described 2 angles of the rootlets until they exit through their respective intervertebral foramen; the rootlets first descend to a level slightly below their respective intervertebral foramen, and then ascend to reach the foramen, thereby forming 2 angles. However the present study showed only a single angle. The second angle reported by Sunderland ${ }^{14}$ can be related to the position of the cadaver.

A C5 palsy is a complication that may occur after laminoplasty. The incidence in the literature ranges between 5\% and 17\%. ${ }^{15-17}$ Various surgical techniques had been introduced to reduce the rate of $\mathrm{C} 5$ palsy, such as unilateral ${ }^{18,19}$ or bilateral foraminotomy. ${ }^{20}$ Several theories have been proposed to explain the occurrence of postoperative C5 palsy. Among these theories, the short and the acute angle of the C5 spinal nerve rootlets and larger distance of posterior shift of the spinal cord at C5 compared to other spinal levels predispose the C5 spinal nerve root to traction injury. ${ }^{21}$ The present anatomic study confirms the acute angle of the C5 $\left(54.5^{\circ} \pm\right.$ $3.3^{\circ}$ ) compared to other cervical spinal levels.

\section{The Diameter of Cervical Spinal Nerves, Number of Dorsal Rootlets and DREZ Distance}

The number of rootlets was most numerous at $\mathrm{C} 6$ $(8.25 \pm 0.6)$ and $C 7(7.25 \pm 0.9)$. Karatas et $\mathrm{al}^{22}$ reported that the maximum number of dorsal rootlets occurred at $\mathrm{C} 6, \mathrm{C} 7$ and $\mathrm{C} 8$. Liu et $\mathrm{al}^{4}$ counted the number of rootlets in the dorsal and ventral roots of the spinal nerves using histological sections and reported that the $\mathrm{C} 7$ dorsal root contained the highest number of nerve fibers among the cervical roots. The result of the present study was consistent with Karatas et $\mathrm{al}^{22}$ but contradicts Liu et $\mathrm{al}^{4}$; the difference may be related to the different methods used in the 2 studies. The results of recent studies have shown that root reimplantation might become a treatment option in brachial plexus injuries. ${ }^{23,24}$ Clinical and experimental animal studies showed that the reimplantation of approximately $40 \%$ of the rootlets can be enough to recover the normal function in the case of a nerve cut. $^{25}$ Thus, knowledge of the number of rootlets may be helpful during neuroanastomosis surgery. 
The DREZ operations are performed for the purpose of lesioning patients with advanced cancer, brachial plexus avulsion, postherpetic neuralgia, spinal cord injury, or hyperspasticity unresponsive to medical or neuromodulatory treatment or to implantation of a medical device, which includes the lesioning of the proximal portion of the dorsal nerve rootlets. Hung and Zhao ${ }^{11}$ measured the DREZ lengths of $\mathrm{C} 5$ to $\mathrm{T} 1$ and reported that the lengths of the DREZ ranged from 9 to $19 \mathrm{~mm}$ with a mean between 11.2 to $14.7 \mathrm{~mm}$. They were longer for the upper roots. The rootlet zones of $\mathrm{C} 5$ and $\mathrm{C} 6$ were approximately $2 \mathrm{~mm}$ longer than those of $\mathrm{C} 7, \mathrm{C} 8$, and T1. In accordance with the results of the above study, the present study also showed the longest average DREZ length was at C5 and C6. The knowledge of the length of the dorsal roots at the specific cervical spinal level can be of importance for the neurosurgeon.

Kobayashi et $\mathrm{al}^{26}$ measured the width of $\mathrm{C} 3$ to $\mathrm{C} 8$ spinal nerves in the vertebral foramen on cadavers and found that $\mathrm{C} 8$ was significantly smaller than the rest of the cervical spinal nerves. Matsuoka et $\mathrm{al}^{27}$ measured the diameter of $\mathrm{C} 5, \mathrm{C} 6$, and $\mathrm{C} 7$ using ultrasound and found that C7 was the largest. Further, a similar study performed by Takeuchi et $\mathrm{al}^{21}$ found C6 was the largest. In the present study, we measured $\mathrm{C} 5$ and $\mathrm{C} 6$ with the largest and C1 with the smallest width.

\section{The Anatomical Relations Between the Vertebral Artery and the Cervical Spinal Nerves}

The vertebral artery enters the transverse foramen of C6 and ascends through the osseous tunnel of cervical vertebrae. The vertebral artery lies anterior to the cervical spinal nerves throughout its course.

Clinical studies have shown that vertebral artery loop formation can cause bony erosion of the intervertebral foramen and compress the cervical spinal nerve roots causing cervical radiculopathy. ${ }^{3,28}$ Anomalous configuration of the vertebral $\operatorname{artery}^{29,30}$ and cervical trauma ${ }^{31}$ can be the cause of vertebral artery loop formation and produce symptomatic compression of the adjacent nerve root. ${ }^{32-35}$ Further, cluster-like headaches have been reported due to positional compression of the $\mathrm{C} 3$ spinal nerve between loops of the vertebral artery ${ }^{36}$ Surgical decompression is the choice of treatment if chronic pain becomes refractory. The present study provides data on the relations of the vertebral artery to the spinal cord for the first time in literature. The knowledge of detailed anatomy of the vertebral artery and its relations with the cervical spinal nerves can avoid complications. The unique relationship of the cervical spine nerves with the vertebral artery must be considered when applying decompression of the vertebral artery. Further, the minimal distance between the vertebral artery and the spinal cord should be considered for pedicle screw fixation.

\section{The Distance Between Respective Cervical Spinal Nerves}

The distance between respective spinal nerves ranged between 9 and $11.8 \mathrm{~mm}$ with an average of $10.3 \pm 1.0$ $\mathrm{mm}$ (see Table 2). The distance between cervical spinal nerves can be important especially in the posterior cervical instrumentation surgery (eg, pedicle or lateral mass screw insertions); by means of predicting the distances between respective cervical spinal nerves, it's certainly an advantage to know the possible localization of the adjacent nerve in order to determine the next screw insertion point and trajectory. While decompressing a cervical spinal nerve at any level in minimally invasive approaches, margins of the bony decompression can be determined much more easily if it's possible to locate the adjacent cervical spinal nerves according to the distances between them, which will avoid neural tissue damage and unnecessary bone loss that may lead to instability of the related level of the vertebral column. The present study provides measurements related to the distance between respective cervical spinal nerves for the first time in literature.

A limitation of the study was the number of cadavers.

\section{Conclusion}

The detailed knowledge of the relations of the vertebral artery and the cervical spinal nerves may assist spine surgeons in minimizing complications during the surgery on the region and may contribute to patho-mechanisms of various disorders.

\section{REFERENCES}

1. Jeszenszky DJ, Haschtmann D, Pröbstl O, Kleinstück FS, Heyde CE, Fekete TF. Tumors and metastases of the upper cervical spine (C0-2). A special challenge. Orthopade. 2013;42(9):746-754.

2. Mattei TA, Mendel E. En bloc resection of primary malignant bone tumors of the cervical spine. Acta Neurochir (Wien). 2014;156(11):2159-2164. 
3. Chibbaro S, Mirone G, Yasuda M, Marsella M, Di Emidio P, George B. Vertebral artery loop - a cause of cervical radiculopathy. World Neurosurg. 2012;78(3-4):375.e11-375.e13.

4. Liu G, Reyes MR, Riew KD. Why does C5 palsy occur after prophylactic bilateral C4-5 foraminotomy in open-door cervical laminoplasty? A risk factor analysis. Global Spine J. 2017;7(7):696-702.

5. Yu YL, du Boulay GH, Stevens JM, Kendall BE. Morphology and measurements of the cervical spinal cord in computer-assisted myelography. Neuroradiology. 1985;27(5):399402.

6. Sakamoto T, Neo M, Nakamura T. Transpedicular screw placement evaluated by axial computed tomography of the cervical pedicle. Spine (Phila Pa 1976). 2004;15;29(22):25102515.

7. Yone K, Sakou T, Yanase M, Ijiri K. Preoperative and postoperative magnetic resonance image evaluation of the spinal cord in cervical myelopathy. Spine. 1992;17(suppl 10):388-392.

8. Fujiwara K, Yonenobu K, Hiroshima K, Ebara S, Yamashita K, Ono K. Morphometry of the cervical spinal cord and its relation to pathology in cases with compression myelopathy. Spine. 1988;13(11):1212-1216.

9. Thijssen HOM, Keyser A, Horstink MWM, Meijer E. Morphology of the cervical spinal cord on computed myelography. Neuroradiology. 1979;18(2):57-62.

10. Liu Y, Zhou X, Ma J, Ge Y, Cao X. The diameters and number of nerve fibers in spinal nerve roots. $J$ Spinal Cord Med. 2015;38(4):532-537.

11. Hung LK, Zhao X. Relationship of cervical spinal rootlets and the inferior vertebral notch. Clin Orthop Relat Res. 2003;(409):131-137.

12. Frykholm R. Lower cervical nerve roots and their investments. Acta Chir Scand. 1951;101(6):457-716.

13. Shinomiya K, Okawa A, Nakao K, et al. Morphology of C5 ventral nerve rootlets as part of dissociated motor loss of deltoid muscle. Spine (Phila Pa 1976). 1994;15;19(22):25012504.

14. Sunderland S. Nerves and Nerve Injuries. 2nd ed. Edinburgh, Scotland: Churchill-Livingstone; 1978:786.

15. Kawaguchi Y, Kanamori M, Ishihara H, Ohmori K, Nakamura H, Kimura T. Minimum 10-year follow up after en bloc cervical laminoplasty. Clin Orthop Relat Res. 2003;2003(411):129-139.

16. Wada E, Suzuki S, Kanazawa A, Matsuoka T, Miyamoto S, Yonenobu K. Subtotal corpectomy versus laminoplasty for multilevel cervical spondylotic myelopathy: a long-term follow-up study over 10 years. Spine (Phila Pa 1976). 2001;26(13):1443-1448.

17. Uematsu Y, Tokuhashi Y, Matsuzaki H. Radiculopathy after laminoplasty of the cervical spine. Spine (Phila Pa 1976). 1998;23(19):2057-2062.

18. Baba H, Chen Q, Uchida K, Imura S, Morikawa S, Tomita K. Laminoplasty with foraminotomy for coexisting myelopathy and unilateral radiculopathy. A preliminary report. Spine (Phila Pa 1976). 1996;21:196-202.

19. Komagata M, Nishiyama M, Endo K, Ikegami $\mathrm{H}$, Tanaka S, Imakiire A. Prophylaxis of C5 palsy after cervical expansive laminoplasty by bilateral partial foraminotomy. Spine J. 2004;4:650-655.

20. Katsumi K, Yamazaki A, Watanabe K, Ohashi M, Shoji
H. Can prophylactic bilateral $\mathrm{C} 4 / \mathrm{C} 5$ foraminotomy prevent postoperative C5 palsy after open-door laminoplasty? A prospective study. Spine (Phila Pa 1976). 2012;37:748-754.

21. Takeuchi M, Wakao N, Kamiya M, et al. Morphological distinction of cervical nerve roots associated with motor function in 219 healthy volunteers: a multicenter prospective study. Spine (Phila Pa 1976). 2014;15;39(16):E944-E949.

22. Karatas A, Caglar S, Savas A, Elhan A, Erdogan A. Microsurgical anatomy of the dorsal cervical rootlets and dorsal root entry zones. Acta Neurochir (Wien). 2005;147(2):195-199.

23. Carlstedt T, Grane P, Hallin RG, Norén G. Return of function after spinal cord implantation of avulsed spinal nerve roots. Lancet. 1995;18;346(8986):1323-1325.

24. Hoffmann CF, Thomeer RT, Marani E. Reimplantation of ventral rootlets into the cervical spinal cord after their avulsion: an anterior surgical approach. Clin Neurol Neurosurg. 1993;95(suppl):S112-S118.

25. Kalantarian B, Rice DC, Tiangco DA, Terzis JK. Gains and losses of the XII-VII component of the "baby-sitter" procedure: a morphometric analysis. J Reconstr Microsurg. 1998;14(7):459-471.

26. Kobayashi $R$, Iizuka $H$, Nishinome $M$, Iizuka $Y$, Yorifuji H, Takagishi K. A cadaveric study of the cervical nerve roots and spinal segments. Eur Spine J. 2015;24(12):2828.

27. Matsuoka N, Kohriyama T, Ochi K, et al. Detection of cervical nerve root hypertrophy by ultrasonography in chronic inflammatory demyelinating polyradiculoneuropathy. J Neurol Sci. 2004;15;219(1-2):15-21.

28. Hage ZA, Amin-Hanjani S, Wen D, Charbel FT. Surgical management of cervical radiculopathy caused by redundant vertebral artery loop. J Neurosurg Spine. 2012;17(4):337-341.

29. Zimmerman HB, Farrell WJ. Cervical vertebral erosion caused by vertebral artery tortuosity. Am J Roentgenol Radium Ther Nucl Med. 1970;108:767-770.

30. Bruneau M, Cornelius JF, Marneffe V, Triffaux M, George B. Anatomical variations of the V2 segment of the vertebral artery. Neurosurgery. 2006;59(suppl 1):ONS20-4.

31. Lindsey RW, Piepmeier J, Burkus JK. Tortuosity of the vertebral artery: an adventitious finding after cervical trauma. A case report. J Bone Joint Surg Am. 1985;67(5):806-808.

32. Aggarwal A, Burton K. Cervical root injury caused by vertebral artery dissection. J Clin Neurosci. 1999;6(2):166-168.

33. Sakaida H, Okada M, Yamamoto A. Vascular reconstruction of a vertebral artery loop causing cervical radiculopathy and vertebrobasilar insufficiency. Case report. $J$ Neurosurg. 2001;94:145-149.

34. Doweidar A, Al-Sayed S, Al-Kandery S. Symptomatic vertebral artery loop: a case report and review of literature. $J$ Radiol Case Rep. 2014;31;8(5):35-41.

35. Tsuzuki N, Abe R, Saiki K, Zhongshi L. Extradural tethering effects as one mechanism of radiculopathy complicating posterior decompression of the cervical spinal cord. Spine (Phila Pa 1976). 1996;21:203-211.

36. Créac'h C, Barral F, Nuti C, et al. Positional cluster-like headache. A case report of a neurovascular compression between the third cervical root and the vertebral artery. Cephalalgia. 2010;30(12):1509-1513.

Disclosures and COI: This research did not receive any specific grant from funding agencies in 
the public, commercial, or not-for-profit sectors. None of the authors has any conflict of interest to disclose. All cadavers used in this study was donated for medical student's dissections and research purposes. All procedures performed in studies were approved by the Institutional Ethics Committee of Koç University.

Corresponding Author: Safiye Çavdar, Koç University, School of Medicine, Department of
Anatomy, 34450, Sariyer Istanbul Turkey. Phone: 902123381073 Fax: 9021233810 73; Email: scavdar@ku.edu.tr.

Published 28 August 2020

This manuscript is generously published free of charge by ISASS, the International Society for the Advancement of Spine Surgery. Copyright (C) 2020 ISASS. To see more or order reprints or permissions, see http://ijssurgery.com. 